\title{
Social-ecological systems influence ecosystem service perception: a Programme on Ecosystem Change and Society (PECS) analysis
}

\author{
$\underline{\text { Cristina Quintas-Soriano }}^{1,2,3}$, Jodi S. Brandt ${ }^{4}, \underline{\text { Katrina Running }}^{5}, \underline{\text { Colden V. Baxter }}^{1}$, Dainee M. Gibson ${ }^{1}, \underline{\text { Jenna Narducci }}^{2}$ \\ and Antonio J. Castro ${ }^{1,3}$
}

\begin{abstract}
Facing the challenges of environmental and social changes, sustainable management of ecosystem services is a worldwide priority. The Programme on Ecosystem Change and Society (PECS) approach provides a unique opportunity for promoting transdisciplinary place-based comparative research for social-ecological systems (SES) management. As part of the PECS-sponsored WaterSES project, we used four place-based SES research sites to analyze patterns in perceptions of ecosystem services. Our data come from about 1,500 face-to-face surveys conducted in southern Spain, the south-central Great Plains of Oklahoma (USA), and the Portneuf and Treasure Valleys, Idaho (USA). Specifically, this study aimed to (1) describe and compare perceptions of ecosystem services within and across SES sites, (2) explore how perceptions of ecosystem services vary among local respondents and by sociodemographic factors, and (3) evaluate the overall relationship between place-based SES contexts and ecosystem service perceptions. Our results revealed that cultural ecosystem services were the most highly mentioned among those surveyed across all four sites. However, we found differences in how ecosystem services were perceived among the four SES contexts. For instance, both, social (e.g., gender, education) and local ecological (e.g., land use and climate) characteristics play roles in influencing people's perceptions of which services are important. Overall, our findings suggest the relationship between people's perceptions of ecosystem services and their socialenvironmental context is complex, which highlights the value of the PECS approach for crafting more effective and inclusive landscape management strategies.
\end{abstract}

Key Words: cultural ecosystem services; place-based research; social perceptions; stakeholders; WaterSES

\section{INTRODUCTION}

Social-ecological systems (SES) are linked systems of people and nature, emphasizing that humans must be seen as a part of, not apart from, nature (Berkes and Folke 1998). The SES framework provides guidance on how to assess the social and ecological dimensions that contribute to sustainable resource use and management (Ostrom 2009). Within the SES framework, ecological subsystems interact with societies and their institutional systems to generate ecosystem services (ES) that are managed and governed by social subsystems (Berkes and Folke 1998, Ostrom 2009). Because the SES approach explicitly recognizes the connections and feedbacks linking human and natural systems (Leslie et al. 2015), it can be used in the key process of generating knowledge and the formulation of sustainable governance solutions.

The concept of ES was developed to represent the diversity of benefits provided by ecological subsystems for human well-being (Costanza et al. 1997, Daily 1997, Millennium Ecosystem Assessment (MA) 2005). The ES concept has gained considerable attention among scientists as a way to communicate societal dependence on ecological life-support systems that integrates perspectives from both the natural and social sciences (Castro et al. 2011, 2015a). A critical step in ES valuation is to identify both an ecosystem's capacity to provide services, as well as the societal demand for those ES by different stakeholders (Castro et al. 2014, Martín-López et al. 2014). Addressing both dimensions demonstrates that an ES is influenced not only by an ecosystem's properties but also by societal needs (Burkhard et al. 2012, Castro et al. 2013). In turn, perceptions of and preferences for ES depend on social and cultural context (Martín-López et al. 2012) as well as economic context (Turner et al. 2010, Hamman et al. 2016). Thus, ES valuation within different SES is influenced not just by the ecological characteristics of the ecological subsystem, but also by the sociocultural and institutional context of the social subsystem as well (Tallis and Polasky 2009). However, studies rarely address how stakeholder perceptions of ES link to the biophysical properties and functions of the ecosystems on which ES are based, or the degree to which ES are influenced by sociocultural context and human interests and traditions (Cebrián-Piqueras et al. 2017).

In recent decades, different international research initiatives have emerged to facilitate the development and synthesis of SES research aimed at understanding environmental problems and generating sustainability solutions at the local scale (Maass et al. 2016). The Programme on Ecosystem Change and Society (PECS) aims to provide opportunities for synthesizing insights gained from the SES science community that may contribute to global sustainability (Xu et al. 2014) through an approach that relies on comparisons among place-based SES research sites (OterosRozas et al. 2015, Maass et al. 2016, Balvanera et al. 2017a,b, Norström et al. 2017). Here, we use the PECS approach to investigate how different social-ecological contexts influence people's perceptions of ES. With this aim, we (1) describe and compare ES perceptions within and across four place-based SES research sites that have in common water scarcity but that encompass diverse social, ecological, and economic contexts, (2)

${ }^{1}$ Idaho State University, Department of Biological Sciences, Pocatello, Idaho, USA, ${ }^{2}$ Human-Environment Systems Center, Boise State University, Boise, Idaho, USA, ${ }^{3}$ Centro Andaluz para la Evaluación y Seguimiento del Cambio Global (CAESCG), Departamento de Biología Vegetal y Ecología, Universidad de Almería, Almería, Spain, ${ }^{4}$ Human-Environment Systems, Boise State University, Boise, Idaho, USA, ${ }^{5}$ Department of Sociology, Social Work, and Criminology, Idaho State University, USA 
Fig. 1. Map of the locations of the four place-based research sites.

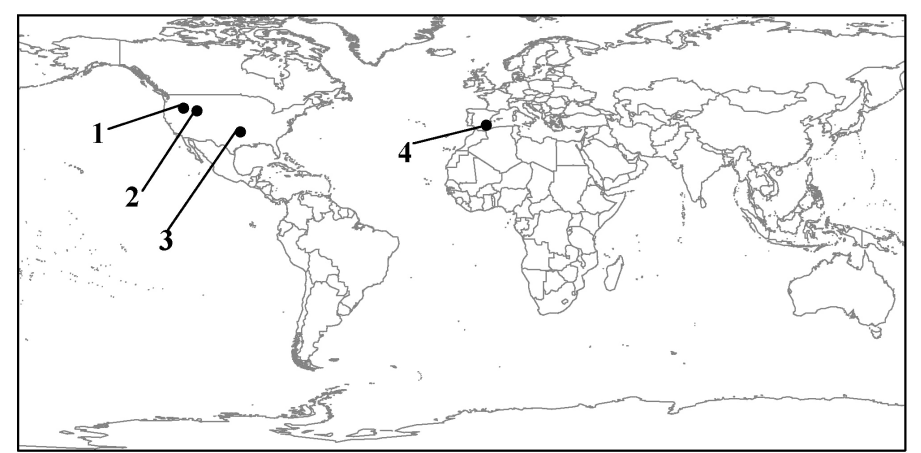

Treasure Valley

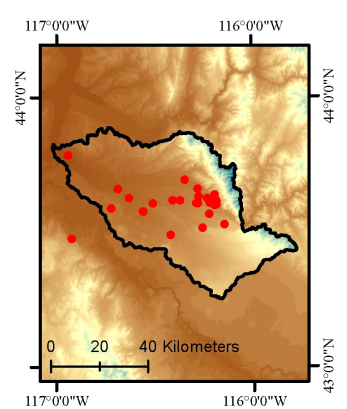

Portneuf Valley

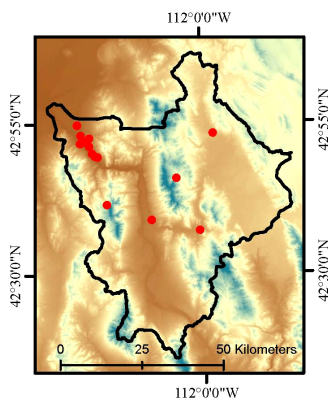

Kiamichi River

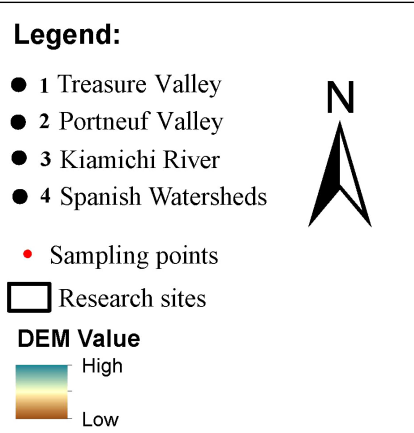

Spanish Watersheds
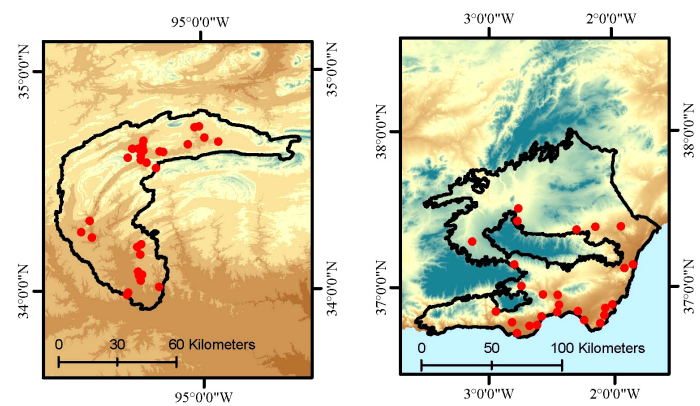

explore how ES perceptions vary among local respondents and among stakeholder groups and the degree to which sociodemographic factors are associated with these perceptions, and (3) evaluate the overall relationship between SES contexts and ES perceptions.

\section{STUDY SITES}

Four place-based SES research sites located in the USA and Spain were chosen to integrate the PECS-WaterSES project (http:// pecswaterses.com/). The four sites represent areas that are experiencing new regional societal demands for limited water resources (Hoff 2009, Sabo et al. 2010, Armas et al. 2011) (Fig. 1). Simultaneously, each site is characterized by different water needs and social-ecological dynamics, which result in different social, ecological, and economic contexts that we expected would influence perceptions of ES. The opportunistic use of these four sites, which are all characterized by water scarcity, provided us with the context within which to evaluate how social, cultural, demographic, and economic variation influences perceptions of ecosystem services, without the overriding environmental impacts on these perceptions that might be expected if sites were compared that differed dramatically in water resources.

\section{Treasure Valley, southwest Idaho}

The Treasure Valley, located in southwestern Idaho (USA), is a lowland area in a mountainous region. This region, covering approximately $3,438 \mathrm{~km}^{2}$ has a semiarid climate with hot, dry summers and moderately long winters. Agricultural lands, including crops and pasture/hay for cattle, account for 34\% of the total land use in the Treasure Valley (National Land Cover Database (NLCD), https://www.mrlc.gov/, 2011). These include industrial-scale production (e.g., potatoes, sugar beets, dairy) responsible for $80-90 \%$ of the region's current water use (Petrich 2016), and that contribute to extensive water quality degradation (Hastings and Williams 2014). Developed areas correspond to $16 \%$ of the land use (Table 1). This region is home to three of Idaho's largest cities (Boise, Nampa, and Meridian; combined population of $\sim 400,000$ ) in an otherwise sparsely populated state; the Boise metropolitan area is one of the fastest growing cities of America with a 120\% population increase between 1990 and 2015 (Forbes Magazine 2016). Increased development is changing traditional land uses, converting farmland into commercial and residential developments, and is projected to increase water demand $250-350 \%$. Rapid urban expansion, coupled with climate change, has produced consequences for the quality and quantity of water supplies, emerging as one of the major challenges in the area (Han et al. 2017).

\section{Portneuf Valley, southeast Idaho}

Located in southeastern Idaho (USA), the Portneuf Valley site $\left(3,436 \mathrm{~km}^{2}\right)$ has a similar climate to the Treasure Valley ( 310 vs. $280 \mathrm{~mm}$ average precipitation, respectively), although it resides at $\sim 500$ m higher elevation, includes more mountainous terrain, and is mostly agricultural. The largest urban area is Pocatello, a midsized city (population $~ 50,000$ ) located along the Portneuf River, a tributary of the larger Snake River, which also drains into the Treasure Valley downstream. The major land uses in the area are agricultural (22\%) with forested areas (17\%) at higher elevations, and only $4 \%$ of the valley is developed land (NCLD 2011). Here, population growth has been only modest $(5-10 \%)$, although urban expansion upstream and into its surrounding foothills is replacing some traditional farming and grazing. Agricultural land use and irrigation water withdrawals (which reduce the base flow of the Portneuf River by an average of $70 \%$ during a regular 
Table 1. Summary of environmental characteristics and social sampling of the four place-based research sites.

\begin{tabular}{|c|c|c|c|c|}
\hline Location & $\begin{array}{c}\text { Treasure Valley } \\
\text { Idaho, US }\end{array}$ & $\begin{array}{l}\text { Portneuf Valley } \\
\text { Idaho, US }\end{array}$ & $\begin{array}{l}\text { Kiamichi River } \\
\text { Oklahoma, US }\end{array}$ & $\begin{array}{c}\text { Spanish Watersheds } \\
\text { Andalusia, Spain }\end{array}$ \\
\hline \multicolumn{5}{|l|}{ Characteristics } \\
\hline Area $\left(\mathrm{km}^{2}\right)$ & 3,438 & 3,436 & 4,719 & 12,207 \\
\hline Altitude range (m.a.s.l.) & $668-2,136$ & $1,328-2,832$ & $0-255$ & $0-2,040$ \\
\hline Total population & 575,001 & 79,747 & 24,214 & 919,405 \\
\hline Population density (people $/ \mathrm{km}^{2}$ ) & 167 & 23 & 5 & 75 \\
\hline Agricultural lands $(\%)$ & 34 & 22 & 18 & 45 \\
\hline Developed lands $(\%)$ & 16 & 4 & 3 & 3 \\
\hline Forest areas $(\%)$ & 1 & 17 & 62 & 12 \\
\hline Water areas $(\%)$ & 1 & 1 & 4 & 1 \\
\hline \multicolumn{5}{|l|}{ Social sampling characteristics } \\
\hline Number of sampling points & 33 & 15 & 30 & 26 \\
\hline Date of sampling & July-August 2016 & July-August 2016 & June-July 2013 & February-April 2012 \\
\hline Sample size $(N)$ & 402 & 326 & 308 & 475 \\
\hline
\end{tabular}

summer; Marcarelli et al. 2010), combined with flood control management of the Portneuf River via levees and concrete channel in and near the city of Pocatello, have reduced water quantity and quality (Hastings and Williams 2014), limiting ecosystem health, recreational opportunities, and rivercommunity connections, which are increasingly desired by residents of Pocatello.

\section{The Kiamichi River watershed, southeast Oklahoma}

The Kiamichi River is a major tributary to the Red River, located in southeastern Oklahoma (USA) (Fig. 1) (Castro et al. 2016a). This area covers $4,719 \mathrm{~km}^{2}$, and the major land classes are forested areas $(62 \%)$ and agricultural lands $(18 \%)$. The region is characterized by steep and rugged terrain, limiting major row crop agriculture. There are no nearby major cities or interstates, and human population density is low (5.13 people $/ \mathrm{km}^{2}$, Table 1). This lack of development in the watershed has left the Kiamichi River with relatively pristine water and high aquatic biodiversity (Vaughn 2017). However, water availability from the two main reservoirs is predicted to decrease over the next 25 years due to increased drought coupled with water demand from an increasing human population outside the watershed, especially from Oklahoma City (a rapidly growing population of $\sim 630,000$ ) (Castro et al. 2016b).

\section{Spanish watersheds, southeast Spain}

The Spanish semiarid watersheds are located on the southeastern Iberian Peninsula, which is considered the most arid region of continental Europe. Covering approximately $12,207 \mathrm{~km}^{2}$, the area has a warm, dry Mediterranean climate with average annual temperatures between 12 and $15^{\circ} \mathrm{C}$ and annual average rainfall of 200-350 mm per year (Armas et al. 2011). Most of the region is dedicated to agricultural uses $(45 \%)$, and approximately $38 \%$ of the area is covered by scrublands and rangelands (Castro et al. 2014, Quintas-Soriano et al. 2016). This region has experienced one of the most dramatic and significant land-use transformations in all of Europe (Quintas-Soriano et al. 2014). This area has become the largest producer of vegetables at the European level, and these commodities have driven the regional economy and the increasing local standard of living. However, conflicts between economic development and conservation have generated recent concern due to the rapid expansion of greenhouse horticulture and the abandonment of rural and mountainous areas (Quintas-Soriano et al. 2016).

\section{METHODS}

\section{Social sampling description}

In each site, individuals were sampled from the population to encompass a wide range of the local citizenry (e.g., residents, environmental experts, or business workers). The sampling frame was restricted to individuals over 18 years old. A total of 1,511 direct face-to-face surveys were compiled across the four sites between 2012 and 2016, in different sampling points across each place-based research site (see Table 1 and Fig. 1 for more details).

\section{Survey development and data collection}

The social survey was administered in each of the four SES research sites. To test the suitability of the questionnaire design, we conducted a preliminary survey in each case study area (Martín-López et al. 2012, Castro et al. 2016a,b). The questionnaires collected information regarding respondents' knowledge about the capacity of each site to provide ES to maintain human well-being and sociodemographic information of the surveyed individuals (i.e., level of education, age, and place of residence). In addition, questions allowed for some comparisons among stakeholder groups (e.g., scientific experts, those engaged in environmental organizations, members of particular cultural groups, etc.). See Appendix 1 for a detailed description of the survey design. The variables obtained from the questionnaire are shown in Appendix 2.

Prior research has explored ES perceptions using qualitative and quantitative techniques that involve direct and indirect consultative methods (Castro et al. 2013). Here, we measured ES perception as the recognition by respondents of the benefits obtained from ecosystem processes (or ES) that are important for sustaining human well-being (Martín-López et al. 2012, Beery et al. 2016). While conducting the surveys, the ES concept was always introduced at the beginning of the face-to-face interaction as "the benefits that the ecosystems of the area provide for human well-being" to make the term more understandable for the remainder of the survey and to avoid educational biases (MartínLópez et al. 2012). To characterize ES perception, we began with a free-listing technique in which respondents were asked to name 
all of the possible benefits they could think of that the ecosystems in the study area provide. We chose to begin this way because the free-listing technique is a direct consultative method that provides spontaneous responses contrary to what happens when a list of given options is suggested in the questionnaire, thereby minimizing framing effects (Martín-López et al. 2012).

Our research assistants began each survey by asking: "Do you think the area and the surrounding region provide benefits or contributions that contribute to human well-being of the region?" Respondents indicated the level of benefits that they thought the region contributed to human well-being and then were asked to provide a list of examples of those potential benefits (see Appendix 1) (Martín-López et al. 2012). The resulting qualitative data from this method produced a long list of aspects mentioned by respondents that were later coded into ES and then grouped in the three main categories of ES - provisioning, regulating, and cultural-by the researchers in a collective reflection process following the international ES classification of the Common International Classification of Ecosystem Services (CICES; $\underline{w w w}$. cices.eu), Haines-Young and Postchin 2013). Ambiguous responses (e.g., "nature," "feeling good") and those that could not be categorized into any ES (e.g., "work," "money") were excluded from the analyses. We then estimated the percentage of respondents in each location who listed specific ES and also the percentage associated with each of the three types of ES.

In addition to these surveys in which sociodemographic characteristics (e.g., age, gender, ethnicity) and the proportion of respondents with various perceptions about ES were measured, we also collected data regarding ecological variables (i.e., land use and environmental) associated with each site, in order to identify if there were any patterns between these and perceptions of ES. In each site, we estimated the percentage of land used for various purposes using the NLCD for the U.S. sites and the land-use and land-cover map of Andalusia for the Spanish site (REDIAM, http://www.juntadeandalucia.es/medioambiente/site/rediam). Using GIS, we then calculated the percentage of each land-use type linked to the respondents' place of residence (e.g., zip code area or municipality). Climate factors such as average precipitation of the wettest month and average temperature of the warmest month were also obtained from WorldClim, a global climate data set (http://www.worldclim.org/), and calculated as the average value for each place-based research site in order to better understand the social-ecological context in which our residents were living.

\section{Data analyses}

Samples collected reflected quite well the average characteristics of the local populations for each site in terms of race/ethnicity, age, education, income, and gender. With respect to the sociodemographic make-up of each site, we found a number of similarities and differences among sites (Table 2). The gender balance was about the same across the four sites, although we surveyed more men on average, especially in the Kiamichi River watershed. In terms of the type of respondents we interviewed, the vast majority of them were basic residents; only in the Spanish watersheds and the Kiamichi watershed did expert respondents constitute approximately $20 \%$ of the sample. The Treasure Valley sample was the oldest ( $45 \%$ respondents older than 50 years), and the Spanish sample the youngest ( $77 \%$ respondents younger than 50 years). The level of income and education of respondents showed similar patterns across sites: the Treasure Valley respondents had the highest level of income and the most respondents with university-level education whereas the Spanish respondents had lower incomes and less university-level education on average. The respondents from the three sites in the USA exhibited a more localized sense of place, indicating a primary affinity for their own city and regional areas, whereas more respondents in the Spanish site reported a sense of place corresponding to the national scale. The sampled population was the most ethnically diverse in the Kiamichi watershed (e.g., $23 \%$ Native American and 7\% multiracial respondents surveyed), whereas the other sites' respondents primarily identified as Caucasian/white. Finally, proactive environmental behavior (measured by membership in an environmental association) was low across the four sites, ranging from $8 \%$ in the Kiamichi to only $3 \%$ in the Portneuf Valley (Table 2).

To evaluate objective 1, we used descriptive statistics to compare how ES perceptions varied within and across the four place-based research sites. We estimated the relative percentage of observations for ES categories, based on the percentage of respondents who provided examples of ES and grouped by ES categories. We then employed the nonparametric Kruskal-Wallis test followed by Dunn's multiple comparison test to analyze the relative importance given to each ES category and to explore differences between sites. We estimated the relative percentage of our respondents that mentioned different types of ES and used a bar graph to visualize those observations across the four placebased research sites.

For objective 2, we explored whether ES perceptions varied among stakeholder groups and people with different sociodemographic characteristics. To do that, the Mann-Whitney U-test and Kruskal-Wallis tests were used to explore if sociodemographic factors (i.e., gender, age, level of education or proenvironmental behavior) influence people's perceptions of different ES categories within sites (See Appendix 2 for a full description of variables and analysis used).

Finally, for objective 3, a redundancy analysis (RDA) was used to explore the degree of influence of social-ecological context on ES perceptions. The RDA (Rao 1964) is a tool commonly used for modeling dependent variables with their hypothetical predictors (Legendre and Legendre 1998). This statistical technique provides the means for conducting direct explanatory analysis, in which the association among ES may be explored with respect to their relationships with any set of predictors of interest. For instance, RDA is commonly used for analyzing how economic and sociocultural variables are related with social values (Hicks et al. 2009, Martín-López et al. 2012). To do so, we identified sociodemographic and ecological factors associated with each place-based research site and examined the relative importance of particular ES linked with sociodemographic and environmental behavior variables. A Monte Carlo permutation test (1000 permutations) was performed to determine the significance of independent variables in determining the relative importance of people's perception of ES (López-Santiago et al. 2014).

XLSTAT 2017 was used to perform the statistical analysis. We used the QGIS 2.8.6-Wien Geographical Information Systems and R 3.1.2 (R Core Team 2015) to estimate land use and climate variable percentages. 
Table 2. Sociodemographic characterization of the four social samples.

\begin{tabular}{|c|c|c|c|c|c|}
\hline & \multirow[t]{2}{*}{ Categories } & \multicolumn{4}{|c|}{$\%$ of respondents } \\
\hline & & $\begin{array}{c}\text { Treasure } \\
\text { Valley }\end{array}$ & $\begin{array}{l}\text { Portneuf } \\
\text { Valley }\end{array}$ & $\begin{array}{l}\text { Kiamichi } \\
\text { River }\end{array}$ & $\begin{array}{c}\text { Spanish } \\
\text { Watersheds }\end{array}$ \\
\hline \multicolumn{6}{|l|}{ Sociodemographic variables } \\
\hline \multirow[t]{2}{*}{ Gender } & Female & 50 & 44 & 43 & 45 \\
\hline & Male & 50 & 56 & 57 & 55 \\
\hline \multirow[t]{2}{*}{ Stakeholder groups } & Residents & 90 & 92 & 82 & 80 \\
\hline & Experts & 10 & 8 & 18 & 20 \\
\hline \multirow[t]{4}{*}{ Age } & $<30$ years & 21 & 36 & 23 & 25 \\
\hline & $30-50$ & 34 & 35 & 40 & 52 \\
\hline & $50-70$ & 37 & 25 & 33 & 20 \\
\hline & $>70$ years & 7 & 5 & 4 & 3 \\
\hline \multirow[t]{3}{*}{ Income } & Low & 32 & 26 & 27 & 3 \\
\hline & Medium & 55 & 57 & 54 & 27 \\
\hline & High & 14 & 17 & 19 & 70 \\
\hline \multirow[t]{3}{*}{ Educational level } & Less than High School & 2 & 2 & 1 & 15 \\
\hline & High School Certificate & 14 & 14 & 33 & 43 \\
\hline & University/College & 83 & 85 & 66 & 42 \\
\hline \multirow[t]{4}{*}{ Sense of place } & City/county & 26 & 6 & 23 & 27 \\
\hline & State/Region & 48 & 66 & 56 & 39 \\
\hline & Country & 25 & 28 & 19 & 27 \\
\hline & World/Global & 1 & 1 & 1 & 8 \\
\hline \multirow[t]{7}{*}{ Ethnic background } & White & 86 & 76 & 64 & - \\
\hline & Black, African American & 3 & 8 & 3 & - \\
\hline & Native American & 1 & 3 & 23 & - \\
\hline & Asian American & 1 & 2 & - & - \\
\hline & Latino or Hispanic & 5 & 6 & - & - \\
\hline & Multiracial & 3 & 1 & 7 & - \\
\hline & Other & 2 & 4 & 3 & - \\
\hline \multicolumn{6}{|l|}{ Environmental behavior } \\
\hline \multirow{2}{*}{$\begin{array}{l}\text { Environmental association } \\
\text { membership }\end{array}$} & Yes & 7 & 3 & 8 & 5 \\
\hline & No & 93 & 97 & 92 & 95 \\
\hline Number of Respondents & & 402 & 326 & 308 & 475 \\
\hline
\end{tabular}

\section{RESULTS}

\section{Ecosystem services perceptions within and across place-based} research sites

We found similar trends in the ES category favored by local respondents across the four sites: cultural services were perceived as the most important service category by respondents, followed by provisioning and regulating services. Only in the Portneuf Valley did respondents perceive cultural and provisioning service categories with a similar level of importance (56-57\%; Table 3). The ES that were most commonly identified across the four sites were tourism, food from agriculture, and water supply. Recreational fishing, esthetic values and habitat were also widely recognized, whereas ES such as climate regulation and alternative energy were less frequently identified (Fig. 2).

We also detected several different patterns in the specific ES most highly valued across the four sites (see Fig. 2). Specifically, respondents in the Treasure Valley perceived the highest diversity of ES as important, with high importance placed on all services relative to the other sites. In the Portneuf Valley, water provision, habitat quality and existence values were perceived as most important (as shown in the Dunn group results; Appendix 3). Overall, respondents in the Kiamichi site perceived fewer ES as
Fig. 2. Bar graph of the percentage of respondents that perceived different ecosystem services across the four placebased research SES sites.

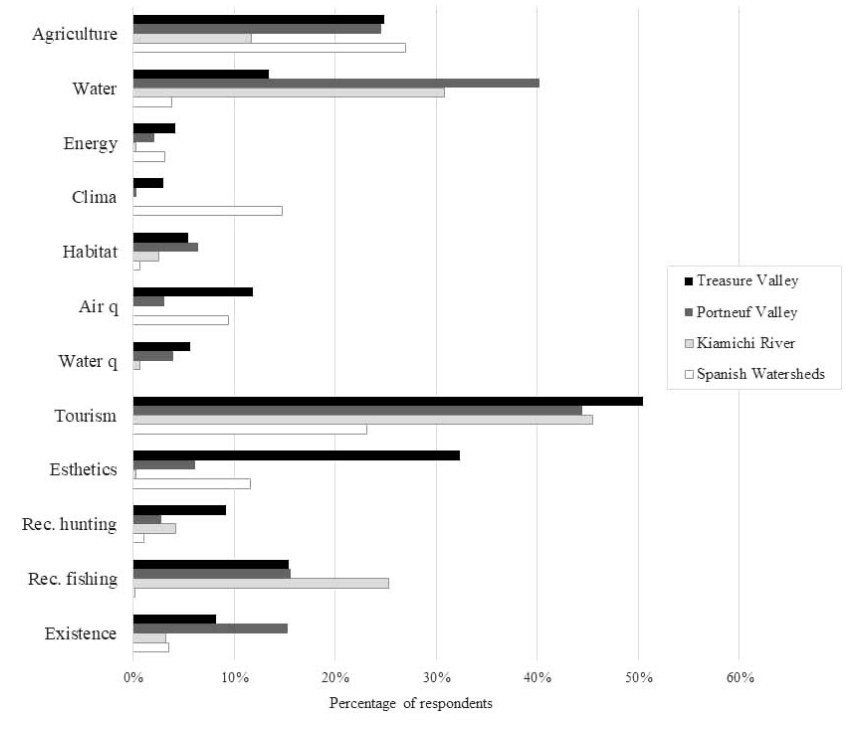


Table 3. Percentage of respondents that provided examples of ecosystem services grouped by categories (i.e., provisioning, regulating, and cultural) (*** indicate statistical significance at the 0.01 level).

\begin{tabular}{|c|c|c|c|c|c|c|c|}
\hline \multirow[b]{2}{*}{ Case studies } & \multirow[b]{2}{*}{$N$} & \multicolumn{6}{|c|}{$\%$ of respondents perceived the area provides benefits } \\
\hline & & Provisioning & $\begin{array}{l}\text { Dunn } \\
\text { groups }\end{array}$ & Regulating & Dunn groups & Cultural & $\begin{array}{l}\text { Dunn } \\
\text { groups }\end{array}$ \\
\hline Treasure Valley & 402 & 36 & $\mathrm{~B}$ & 19 & A & 77 & $\mathrm{~B}$ \\
\hline Portneuf Valley & 326 & 56 & A & 12 & $\mathrm{~B}$ & 57 & A \\
\hline Kiamichi River & 308 & 37 & $\mathrm{~B}$ & 3 & $\mathrm{C}$ & 58 & A \\
\hline Spanish Watersheds & 475 & 32 & $\mathrm{~B}$ & 24 & A & 35 & $\mathrm{C}$ \\
\hline Mean & & 40 & & 14 & & 57 & \\
\hline Kruskal-Wallis Test & & $53 * * *$ & & $7 * * *$ & & $161 * * *$ & \\
\hline
\end{tabular}

important, except for tourism and water provision (Appendix 3). In particular, climate regulation and air quality were not perceived as important in this site (no respondents mentioned it), and we also found smaller proportions of respondents mentioning esthetic values, water quality and energy there compared with the other sites. In the case of the Spanish watersheds, water quality was not brought up as a perceived ES, and recreational fishing and hunting were only mentioned rarely. On the other hand, climate regulation and esthetic values were frequently noted during the free-listing exercise among respondents at this site, in contrast to the other place-based research sites.

\section{Influence of sociodemographic factors on ecosystem services perceptions}

Across the four sites, we found that different sociodemographic factors related to the perception of the three ES categories (Table 4). In the Treasure Valley, we observed that only age, and whether or not a respondent was a scientific expert or donated to an environmental organization affected ES perception. In particular, expert respondents perceived both more provisioning and regulating services, whereas the cultural ES category was not influenced by the type of stakeholder. Respondents with a membership in an environmental association perceived the regulating and cultural service categories more than those without. In addition, respondents older than $30 \mathrm{yr}$ old were more likely to perceive ES from the provisioning service category, whereas respondents under $30 \mathrm{yr}$ old more frequently mentioned cultural ES. In the Portneuf Valley, other variables such as level of income, sense of place, and gender were associated with perceiving provisioning services. For instance, males, respondents with a global sense of place, and respondents with a high level of income perceived provisioning services more than did females, respondents with more localized identities, or people with lower levels of income. In contrast, respondents with less than a high school education were more likely to mention cultural services (e.g., recreational hunting and fishing) in their free-listing exercise.

In the Kiamichi site, the cultural service category was the ES that exhibited the most differences associated with sociodemographic variables such as level of income, sense of place, education, expert status, and age. For instance, nonexpert resident stakeholders, respondents under $30 \mathrm{yr}$ old, respondents with a high school education and a high level of income, noted their appreciation of cultural services more than did their counterparts.
Finally, in the Spanish watersheds, we observed many variables significantly affecting ES perceptions. Level of education affected all three ES categories. Particularly, respondents with a level of education lower than high school perceived provisioning ES more frequently, whereas respondents with a university education were more likely to perceive the regulating and cultural service categories. Experts also tended to perceive cultural services as important, but residents were more prone to perceive provisioning ES as important. Finally, respondents with moderate income levels and with a global sense of place perceived importance of cultural services the most (Table 4).

\section{Degree of influence of social-ecological context on ecosystem services perceptions}

Through multivariate analysis of RDA, we detected the presence of significant associations between both sociodemographic and ecological characteristics and how respondents perceived individual ES $(P<0.001$, from 1000 permutations). The first two axes of the RDA explained $78 \%$ of the total variance (Fig. 3). The first axis of the RDA ( $49 \%$ of the variance) revealed a gradient across the four case studies. The most negative scores were associated with the Spanish watersheds relative to the perception of climate regulation, agricultural land uses, and warmest temperatures. Additionally, separation along this axis was associated with the fact that people without a membership in an environmental organization were more common in the Spanish sites. The Treasure Valley site position along this axis was linked to the perception of air quality, esthetic values, and food from agriculture, as well as female and expert respondent groups. Positive scores were associated with Kiamichi River and Portneuf Valley, as respondents in both held similar perceptions regarding water provision. The latter two sites were also linked with male resident respondents, a regional sense of place, and ecological variables of the wettest month and forested land uses. The second axis of the RDA ( $29 \%$ of the variance) revealed a gradient of ecosystem service perception whereby most of the regulating and cultural services were related with respondents with environmental memberships and a sense of place related to larger areas (e.g., country and global vs. local or regional). Moreover, respondents with higher levels of education, age, and income showed a clear awareness of regulating and cultural service categories, as well as urban land uses (Fig. 3; Appendix 4).

\section{DISCUSSION}

One of the most interesting findings from this comparative study is that, when asked to think about the benefits from nature they most valued, respondents in all four of our study sites mentioned 
Fig. 3. RDA analysis across the four place-based research sites. The biplot shows the relationships between respondents' perceptions toward particular ecosystem services and variables related to respondents' characteristics (i.e., sociodemographic variables), ecological variables, and place-based research sites. Variables in bold represent explaining variables with higher standardized canonical coefficients for axes 1 and 2. Detail legend: circles = ecosystem services; triangles = sociodemographic variables of respondents; diamonds = ecological variables of SES sites; squares = SES research sites. (LU agri = agricultural land use, LU urb = urban land use, LU for = forest land use, LU wat = water land use).

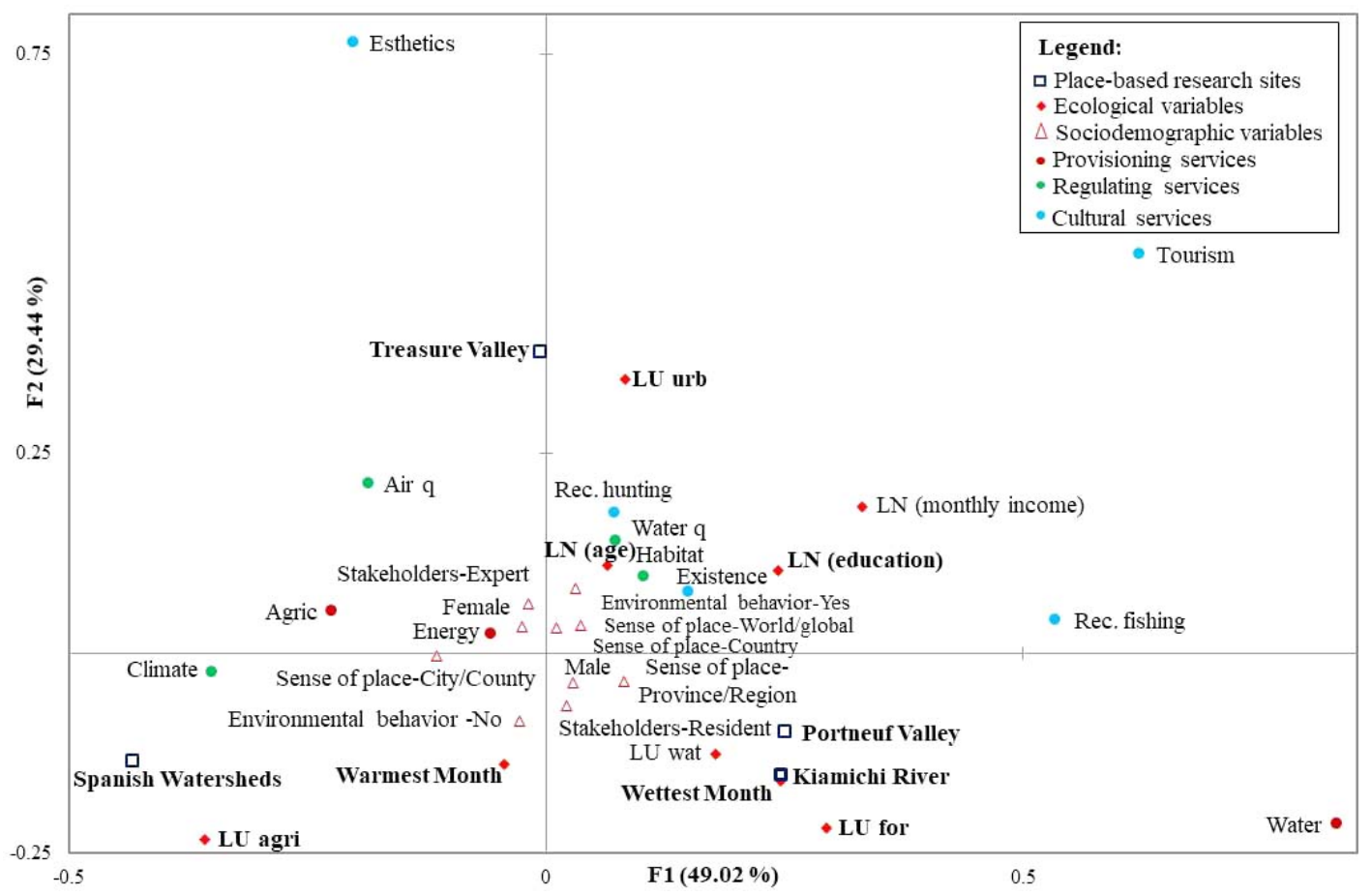

specific cultural ES more often than provisioning and regulating ES. This is somewhat surprising because it contradicts prior studies of ES trends that have found the general public traditionally favors the preservation of provisioning services at the expense of regulating and cultural services, likely because their value is more tangible and quantifiable by traditional societal measures such as monetary worth (Rodríguez et al. 2006, Agbenyega et al. 2009, Hartter 2010). Unlike past research that has found local citizens reporting provisioning services as the most important, our results suggest local populations are highly engaged with their surrounding ecosystems and actively appreciate their capacity to provide cultural ES such as recreation, fishing, hunting, or hiking. In addition, and as shown in previous studies, larger proportions of residents valuing cultural ES vs. provisioning or regulating ES are not explained by an urban context (García-Llorente et al. 2016). In fact, we found respondents in the Treasure and Portneuf sites expressed similar sentiments about cultural ES, despite their difference in total urban population $(600,000$ vs. 60,000 respectively).

Overall, our finding that cultural ES were especially perceived by respondents to our spontaneous, free-listing surveys can be interpreted in the context of two points. First, as prior studies have shown, cultural ES may be more likely to be mentioned when using the free-listing approach for measuring which ES respondents prioritize (Martín-López et al. 2012, Garrido et al.
2017). Second, it is important to consider and highlight the strong influence that recreational activities have on the cultural identities and economies of all four sites. For instance, in the Idaho sites, the Idaho Tourism Division of the Department of Commerce reported that, in 2015 , the tourism industry generated $\$ 3.3$ billion and employed 41,600 people in Idaho, making it the third largest industry in the state. Moreover, the Idaho economy benefits from an average of $\$ 1.6$ billion in annual spending on wildlife-related recreation alone, according to the United States Fish and Wildlife Service. This same touristic tendency occurs in the Spanish site, where statistics shows that tourism in 2017 was up $30 \%$ on the 15 yr average since 2000 .

Another significant similarity among all four of the study sites was the relationship we observed between an individual's placebased identity and their interest in climate regulation. Here, we found that people who reported having a global sense of place were more likely than those with primarily local or regional identities to list climate regulation as a prioritized ES. This is particularly true in the Spanish site. It is generally acknowledged that public awareness of climate change is growing worldwide. Giving that the surveys in Spain predated those in Idaho by $4 \mathrm{yr}$, we might have expected more climate change awareness in the Idaho sites compared with either the Oklahoma or Spanish sites, however, we observed the opposite, which suggests this limitation is not influencing the temporal differences in survey sampling. 
Table 4. Mean relative value based on the number of examples of ecosystem services listed by respondents and grouped by categories, and the factors influencing those people's perceptions of different services categories. Statistically significant results are shown for the stakeholder type, environmental behavior, age, and gender (Mann-Whitney U test) and for education level, sense of place, and level of income (Kruskal-Wallis test). Statistical significance at the $*<0.1, * *<0.05, * * * 0.001$ levels. Prov. $=$ Provisioning services, Reg. $=$ Regulating services, Cult. $=$ Cultural services.

\begin{tabular}{|c|c|c|c|c|c|c|c|c|c|c|c|c|c|}
\hline \multirow[t]{2}{*}{ Variables } & & \multicolumn{3}{|c|}{ Treasure Valley } & \multicolumn{3}{|c|}{ Portneuf Valley } & \multicolumn{3}{|c|}{ Kiamichi River } & \multicolumn{3}{|c|}{ Spanish Watersheds } \\
\hline & & Prov. & Reg. & Cult. & Prov. & Reg. & Cult. & Prov. & Reg. & Cult. & Prov. & Reg. & Cult. \\
\hline \multirow[t]{3}{*}{ Stakeholders } & Residents & 0.38 & 0.17 & & & 0.11 & 0.82 & & & 0.84 & 0.35 & & 0.31 \\
\hline & Experts & 0.77 & 1.05 & & & 0.44 & 1.11 & & & 0.56 & 0.22 & & 0.52 \\
\hline & $\mathrm{U}$ & $5062 * * *$ & $3650 * * *$ & & & $3353 * *$ & $3219^{*}$ & & & $8153 * *$ & $20718 * *$ & & $14509^{* * *}$ \\
\hline \multirow{3}{*}{$\begin{array}{l}\text { Environmental } \\
\text { behavior }\end{array}$} & Yes & & 0.72 & 1.41 & & 0.3 & & & & & & & 0.54 \\
\hline & No & & 0.23 & 1.14 & & 0.13 & & & & & & & 0.34 \\
\hline & $\mathrm{U}$ & & $7497 * * *$ & $6497 *$ & & $1870 *$ & & & & & & & $6507 * *$ \\
\hline \multirow[t]{6}{*}{ Age } & $>30$ years & 0.61 & & 0.95 & & & 0.7 & & & 0.61 & & & \\
\hline & $<30$ years & 0.38 & & 1.21 & & & 0.92 & & & 0.84 & & & \\
\hline & $\mathrm{U}$ & $16240 * * *$ & & $11437 *$ & & & $10484^{* *}$ & & & $7139.50^{* *}$ & & & \\
\hline & $>70$ years & & & & & & & & & & & 0 & \\
\hline & $<70$ years & & & & & & & & & & & 0.25 & \\
\hline & $\mathrm{U}$ & & & & & & & & & & & $2603^{* *}$ & \\
\hline \multirow[t]{3}{*}{ Gender } & Female & & & & 0.58 & & & & & & 0.36 & 0.29 & \\
\hline & Male & & & & 0.74 & & & & & & 0.28 & 0.19 & \\
\hline & $\mathrm{U}$ & & & & $11378^{* *}$ & & & & & & $30188^{*}$ & $31036^{* * *}$ & \\
\hline \multirow[t]{4}{*}{ Education } & Less than High $\mathrm{S}$ & School & & & & & 1.40 & & & 0.5 & 0.48 & 0.14 & 0.21 \\
\hline & High School & & & & & & 0.64 & & & 0.96 & 0.34 & 0.24 & 0.28 \\
\hline & University & & & & & & 0.87 & & & 0.7 & 0.29 & 0.3 & 0.58 \\
\hline & $\mathrm{X}^{2}$ & & & & & & $5.96^{*}$ & & & $9.11^{* *}$ & $8.30 * *$ & $6.82 * *$ & $36.21 * * *$ \\
\hline \multirow[t]{5}{*}{ Sense of place } & City/County & & & & 0.50 & & & 0.42 & & 0.6 & 0.33 & & 0.33 \\
\hline & Province/Region & & & & 0.65 & & & 0.38 & & 0.83 & 0.39 & & 0.41 \\
\hline & Country & & & & 0.71 & & & 0.6 & & 0.92 & 0.34 & & 0.4 \\
\hline & World/global & & & & 1.67 & & & 0.25 & & 0.5 & 0.11 & & 0.58 \\
\hline & $\mathrm{X}^{2}$ & & & & $7.24 *$ & & & $6.96^{*}$ & & $7.13^{*}$ & $9.08 * *$ & & $6.55^{*}$ \\
\hline \multirow[t]{4}{*}{ Income } & High & & & & 0.76 & & & & & 0.98 & & & 0.21 \\
\hline & Medium & & & & 0.69 & & & & & 0.74 & & & 0.54 \\
\hline & Low & & & & 0.46 & & & & & 0.66 & & & 0.35 \\
\hline & $\mathrm{X}^{2}$ & & & & $7.52 * *$ & & & & & $8.44^{* *}$ & & & $14.12 * * *$ \\
\hline
\end{tabular}

This finding aligns with those from prior research on the relationship between the attachment people have to specific pieces of land and what people value about that land; for example, a study by Garrido et al. (2017) connected the species richness associated with oak forests with stronger local identities. Other research has found that identifying oneself as a world citizen is associated with greater concern for global environmental problems like climate change (Running 2013). Thus, our results support the notion that the geographic scale at which one identifies with one's "place" is likely related to one's awareness of climate change and how land use is related to climate dynamics.

With respect to our cross-site comparisons, it is also noteworthy that there were more similarities in how individuals perceived ES between the Portneuf and Kiamichi watersheds compared with any other pair, despite their being geographically much farther apart than the Portneuf and Treasure Valley watersheds. In particular, we found that respondents from the Portneuf Valley and Kiamichi River sites were more likely to prioritize water provisioning over agriculture, whereas in the Treasure Valley and the Spanish sites, the opposite was true. Explanations may lie in the fact that both the Treasure Valley and Spanish sites are characterized by water use to fuel industrial-scale food production, whereas uses in the mountainous, rural Portneuf Valley include proportionately more irrigation of pasturelands, and concerns in the similarly mountainous and rural Kiamichi Basin are centered on diversions for use by growing cities. It is also noteworthy that concerns about water quality were relatively low across all four sites, despite well-documented water quality issues in all four, ranging from thermal alteration in the Kiamichi (Galbraith and Vaughn 2011) to sediment and nutrient pollution in the Treasure and Portneuf Valleys (Hopkins et al. 2011, Han et al. 2017), and aquifer contamination in Spain (Leduc et al. 2017). Other investigators have found that respondents in waterscarce regions were commonly more concerned with water quantity than quality, but that within developed nations like the USA and Spain, variation in social characteristics of respondents may mediate the extent of concerns regarding water quality (e.g., Larson et al. 2016, Flint et al. 2017). For example, proportionately more respondents in the Treasure Valley identified water quality (a regulating ES) as a concern than did those in the other sites, including the nearby Portneuf Valley, which may have been related to differences in the populations sampled, such as the relatively larger proportion of respondents with scientific knowledge and active memberships in environmental organizations.

There were a number of additional notable differences in ES perceptions across the four sites. For example, only in the Portneuf Valley did respondents rate cultural and provisioning services as approximately equal in importance. This could be due to the prominence of the types of farming and ranching in this region, although both the Treasure Valley and the Spanish sites actually have higher proportions of land dedicated to agricultural uses. In addition, recreational hunting and fishing were more highly 
perceived in both of the Idaho sites and the Kiamichi River compared with the Spanish watersheds. To some extent, this may be the result of the strong link between recreational activities and regional identities in U.S. culture (Khakzad and Griffith 2016). In the state of Idaho, hunting and fishing represent activities that are very popular and closely linked with local identity and cultural heritage, whereas in semiarid Spain, those recreational activities are common practices but may not have as much cultural meaning.

Despite the growing interest in ES across global science and policy arenas, the scientific application of ES does not clarify how the information gathered could be used to inform land-policy decisions (Laurans et al. 2013, Quintas-Soriano et al. 2016). Nations are beginning new protocols and policies to start using the ES framework to guide land management policy. Examples of these initiatives are the EU's Rural Development Policy and the National Rural Development Programme for Spain (Law $45 / 2007$ on Rural Development), and the memorandum of the USA's Obama administration directing federal agencies to factor the value of ES into federal planning and decision making.

The analysis of social perceptions has emerged as a first step in the incorporation of social perspectives and stakeholder engagement in environmental management decisions (LópezRodríguez et al. 2015). Global assessments suggest that the tendency is that the general public recognizes first the importance of provisioning ES followed by regulating and cultural services (Martín-López et al. 2012). However, in our sites, cultural ecosystem services were the most perceived in all sites, which suggests that the global policy applications of ES should emphasize cultural ES. However, prioritization of cultural services, especially ES related to recreational activities such as hunting and fishing, can potentially produce ES trade-offs. For instance, in the two Idaho sites in the western USA, land management for cultural services such as recreation or vacation homes in amenity-rich rural landscapes conflicts with the management of land and water resources required to support agriculture. In our Oklahoma site, there is a direct conflict between maintaining water-related recreation activities (e.g., boating and fishing) and supplying water to the urban center of Oklahoma City (Castro et al. 2015b, 2016a,b). Additionally, in Spain, we observed trade-offs between the provision of cultural services (related to luxury recreation opportunities) in places with severe water scarcity issues (Quintas-Soriano et al. 2016, 2018)

The debate about the linkages between cultural services and other ES raises the following question: by promoting land policies that protect specific cultural services (e.g., fishing), are we also protecting other regulating services (e.g., water quality)? Recognizing this complexity is key to understanding the ecological and social implications of different land-based policies, as well as to providing evidence of synergies and trade-offs among multiple types of ES (Castro et al. 2014, 2016b). As recently emphasized by the global assessment of the Intergovernmental Science-Policy Platform on Biodiversity and Ecosystem Services (IPBES), the concept of Nature's contribution to People (NCP) is urgently demanding new tools and approaches to investigate the role that cultural values and identity play in global conservation policies (Díaz et al. 2018), which ultimately helps to advance our knowledge about the linkages between nature and the diversity of its contributions to people (Balvanera et al. 2017a, $b$, Turkelboom et al. 2018).

On a practical level, whereas substantial complexity exists in how and why individuals perceive various ES, our findings suggest a few main things decision makers and land-use planners should consider when formulating new policy. First, people care strongly about their natural environments for recreational, spiritual, and esthetic purposes. There is a growing empirical basis for this trend, and a resulting shift in the way ES are conceptualized, from focusing on economic values to an increasing focus on social values and the incorporation of multiple disciplines characterized by cognitive psychology, nature experience, and place attachment (Ives et al. 2017). In addition, the differences among the four sites highlight the complexity in understanding how people interpret, use, and value physical landscapes. This should not be surprising; the social world is complicated, and different people develop different preferences and environmental orientations under diverse circumstances for a wide variety of reasons (Inglehart 1995, Gelissen 2007, Pisano and Lubell 2015). Overall, our findings suggest that how people come to value the ecosystems around them can best be understood as a combination of biophysical and sociodemographic factors, and that improving our understanding of social-ecological systems to inform sustainability science will require more place-based research in different contexts.

\section{CONCLUSION}

We conducted the same detailed ES survey in four semiarid sites representing very diverse SES contexts: southern Spain, southeastern Oklahoma, southeastern Idaho, and southwestern Idaho. We analyzed the data to understand how the ES local residents in each location cited as important differed between sites and we also synthesized the data to identify which type of ES were mentioned most frequently across all sites. A main conclusion was that cultural ES were the most highly perceived in all four of the research areas, which is important to note because the scientific and policy attention to cultural services is well behind that of regulating and provisioning ES. Our results indicate that, as the majority of our respondents consider cultural ES to be one of nature's primary contributions to human wellbeing, better research and policy are needed to understand and protect cultural ES for humanity's benefit. In particular, a main research priority moving forward should be to better understand if protecting cultural ES requires trade-offs with important regulating and provisioning ES, or whether policy targeting cultural ES can mutually benefit regulating and provisioning ES. Another main conclusion of our study is that both social (e.g., gender, education) and local ecological (e.g., land use and climate) characteristics play roles in influencing people's perceptions of which ES are important. Such findings are only revealed by replicating indepth, place-based research across multiple, diverse sites, and thus confirm the importance of the PECS approach. Overall, our study highlights how the PECS approach can be used to provide both generalizable conclusions about ES valuation commonalities (e.g., cultural services are highly perceived by a wide range of people in diverse sites), while also identifying important factors that are specific to each SES site (e.g., cultural ES like hunting may be valuable to local identities in some places, whereas in others the cultural ES of picnicking is more important), which are important findings to consider when crafting environmental policy about SES management. 
Responses to this article can be read online at: http://www.ecologyandsociety.org/issues/responses. php/10226

\begin{abstract}
Acknowledgments:
This research emerged from the WaterSES project within the Programme on Ecosystem Change and Society (PECS). This publication was made possible by the NSF Idaho EPSCoR Program and by the National Science Foundation under award number IIA-1301792. We certify that the Institutional Review Board (IRB) for the Protection of Human Participants at the University of Oklahoma, at Idaho State University and at Boise State University have approved the IRB protocol with permit numbers 2733, 371 and 107, respectively. The research reported in this paper contributes to the Programme on Ecosystem Change and Society (www.pecsscience.org).
\end{abstract}

\section{LITERATURE CITED}

Agbenyega, O., P. J. Burgess, M. Cook, and J. Morris. 2009. Application of an ecosystem function framework to perceptions of community woodlands. Land Use Policy 26:551-557. http://dx. doi.org/10.1016/j.landusepol.2008.08.011

Armas, C., J. D. Miranda, F. M. Padilla, and F. I. Pugnaire. 2011. Special issue: the Iberian Southeast. Editorial. Journal of Arid Environments 75:1241-1243. http://dx.doi.org/10.1016/j. jaridenv.2011.08.002

Balvanera, P., R. Calderon-Contreras, A. J. Castro, M. FelipeLucia, I. R. Geijzendorffer, S. Jacobs, B. Martín-López, U. Arbieu, C. Ifejika Speranza, B. Locatelli, N. Pérez Harguindeguy, I. Ruiz Mercado, M. J. Spierenburg, A. Vallet, L. Lynes, and L. Gillson. 2017a. Interconnected place-based social-ecological research is needed to inform global sustainability Current Opinion in Environmental Sustainability 29:1-7. http://dx.doi.org/https:// doi.org/10.1016/j.cosust.2017.09.005

Balvanera, P., T. M. Daw, T. Gardner, B. Martín-López, A. Norström, C. Ifejika Speranza, M. Spierenburg, E. M. Bennett, M. Farfan, M. Hamann, J. N. Kittinger, T. Luthe, M. Maass, G. D. Peterson, and G. Pérez-Verdin. 2017b. Key features for more successful place-based sustainability research on social-ecological systems: a Programme on Ecosystem Change and Society (PECS) perspective. Ecology and Society 22(1): 14. http://dx.doi.org/ https://doi.org/10.5751/ES-08826-220114

Baró, F., E. Gómez-Baggethun, and D. Haase. 2017. Ecosystem service bundles along the urban-rural gradient: Insights for landscape planning and management. Ecosystem Services 24:147-159. http://dx.doi.org/10.1016/j.ecoser.2017.02.021

Beery, T., S. Stålhammar, K. I. Jönsson, C. Wamsler, T. Bramryd, E. Brink, N. Ekelund, M. Johansson, T. Palo, and P. Schubert. 2016. Perceptions of the ecosystem services concept: opportunities and challenges in the Swedish municipal context. Ecosystem Services 17: 123-130. http://dx.doi.org/10.1016/j. ecoser.2015.12.002

Berkes, F., and C. Folke, editors. 1998. Linking sociological and ecological systems: management practices and social mechanisms for building resilience. Cambridge University Press, New York, New York, USA.

Burkhard, B., F. Kroll, S. Nedkov, and F. Müller. 2012. Mapping ecosystem service supply, demand and budgets. Ecological Indicators 21:17-29. http://dx.doi.org/10.1016/j.ecolind.2011.06.019

Castro, A. J., M. García-Llorente, B. Martín-López, I. Palomo, and I. Iniesta-Arandía. 2013. Multidimensional approaches in ecosystem services assessment. Pages 441-468 in C. Di Bella and D. Alcaraz-Segura, editors. Earth observation of ecosystem services. CRC Press and Taylor and Francis Group, Boca Raton, Florida, USA.

Castro, A. J., M. García-Llorente, C. Vaughn, J. P. Julian, and C. L. Atkinson. 2016a. Willingness to pay for ecosystem services among stakeholder groups in a south-central US watershed with regional conflict. Journal of Water Resources Management and Planning DOI:10.1061/(ASCE)WR.1943-5452.0000671 http:// dx.doi.org/10.1061/(ASCE)WR.1943-5452.0000671

Castro, A. J., B. Martín-López, M. García-Llorente, P. A. Aguilera, E. López, and J. Cabello. 2011. Social preferences regarding the delivery of ecosystem services in a semiarid Mediterranean region. Journal of Arid Environments 75:12011208. http://dx.doi.org/10.1016/j.jaridenv.2011.05.013

Castro, A. J., B. Martín-López, E. López, T. Plieninger, D. Alcaraz-Segura, C. C. Vaughn, and J. Cabello. 2015a. Do protected areas networks ensure the supply of ecosystem services? Spatial patterns of two nature reserve systems in semi-arid Spain. Applied Geography 60:1-9. http://dx.doi.org/https://doi.org/10.1016/ j.apgeog.2015.02.012

Castro, A. J., C. C. Vaughn, J. P. Julian, and M. García-Llorente. $2016 \mathrm{~b}$. Social demand for ecosystem services and implications for watershed management. Journal of the American Water Resources Association 52(1):209-221. http://dx.doi.org/https://doi. org/10.1111/1752-1688.12379

Castro, A. J., C. Vaughn, J. P. Julian, M. García-Llorente, and K. N. Bowman. 2015b. Social perception and supply of ecosystem services: a watershed approach for carbon related ecosystem services. Pages 443-455 in J. A. Blanco and Y. H. Lo, editors. Biodiversity in ecosystems-linking structure and function. Universidad Publica de Navarra, Spain. http://dx.doi.org/https:// doi.org/10.5772/59280

Castro, A. J., P. Verburg, B. Martín-López, M. García-Llorente, J. Cabello, C. Vaughn, and E. López. 2014. Ecosystem service trade-offs from the supply to social demand: a landscape-scale spatial analysis. Landscape and Urban Planning 132:102-110. http://dx.doi.org/10.1016/j.landurbplan.2014.08.009

Cebrián-Piqueras, M. A., L. Karrasch, and M. Kleyer. 2017. Coupling stakeholder assessments of ecosystem services with biophysical ecosystem properties reveals importance of social contexts. Ecosystem Services 23:108-115. http://dx.doi. org/10.1016/j.ecoser.2016.11.009

Costanza, R., R. Arge, R. de Groot, S. Farber, M. Grasso, B. Hannon, K. Limburg, S. Naeem, R. V. O’Neill, J. Paruelo, R. G. Raskin, P. Sutton, and M. van den Belt. 1997. The value of the world's ecosystem services and natural capital. Nature 387:253260. http://dx.doi.org/10.1038/387253a0 
Daily, G. 1997. Nature's services: societal dependence on natural ecosystems. Island Press, Washington, D.C., USA.

Díaz, S., U. Pascual, M. Stenseke, B. Martín-López, R. T. Watson, Z. Molnár, R. Hill, K. M. A. Chan, I. A. Baste, K. A. Brauman, S. Polasky, A. Church, M. Lonsdale, A. Larigauderie, P. W. Leadley, A. P. E. van Oudenhoven, F. van der Plaat, M. Schröter, S. Lavorel, Y. Aumeeruddy-Thomas, E. Bukvareva, K. Davies, S. Demissew, G. Erpul, P. Failler, C. A. Guerra, C. L. Hewitt, H. Keune, S. Lindley, and Y. Shirayama. 2018. Assessing nature's contributions to people. Science 359:270-272. http://dx.doi. org/10.1126/science.aap8826

Flint, C. G., X. Dai, D. Jackson-Smith, J. Endter-Wada, S. K. Yeo, R. Hale, and M. K. Dolan. 2017. Social and geographic contexts of water concerns in Utah. Society and Natural Resources 30(8):885-902. http://dx.doi.org/10.1080/08941920.2016.1264653

Forbes Magazine. 2016. America's fastest growing cities. [online] URL: https://www.forbes.com/pictures/emeg45ehgji/17-boise-cityidaho/\#43429abe50f4

Galbraith, H. S., and C. C. Vaughn. 2011. Effects of reservoir management on abundance, condition, parasitism and reproductive traits of downstream mussels. River Research and Applications 27(2):193-201. http://dx.doi.org/10.1002/rra.1350

García-Llorente, M., A. J. Castro, C. Quintas-Soriano, I. López, H. Castro, C. Montes, and B. Martín-López. 2016. The value of time in biological conservation and supplied ecosystem services: a willingness to give up time exercise. Journal of Arid Environments 124:13-21. http://dx.doi.org/10.1016/j.jaridenv.2015.07.004

Garrido, P., M. Elbakidze, and P. Angelstam. 2017. Stakeholders' perceptions on ecosystem services in Östergötland's (Sweden) threatened oak wood-pasture landscapes. Landscape and Urban Planning 158:96-104. http://dx.doi.org/10.1016/j.landurbplan.2016.08.018

Gelissen, J. 2007. Explaining popular support for environmental protection: a multilevel analysis of 50 nations. Environment and Behavior 39:392-415. http://dx.doi.org/10.1177/0013916506292014

Haines-Young, R. and M. Potschin. 2013. Common international classification of ecosystem services (CICES): consultation on version 4, August-December 2012. European Environment Agency (EEA) Framework Contract No. EEA/IEA/09/003, EEA, Copenhagen, Denmark.

Hamman, H., R. Biggs, and B. Reyers. 2016. An exploration of human well-being bundles as identifiers of ecosystem service use patterns. PLoS One 11(10):e0163476. http://dx.doi.org/10.1371/ journal.pone. 0163476

Han, B., S. G. Benner, J. P. Bolte, K. B. Vache, and A. N. Flores. 2017. Coupling biophysical processes and water rights to simulate spatially distributed water use in an intensively managed hydrologic system. Hydrology and Earth System Sciences 21:3671-3685. http://dx.doi.org/10.5194/hess-21-3671-2017

Hartter, J. 2010. Resource use and ecosystem services in a forest park landscape. Society and Natural Resources 23:207-223. http:// dx.doi.org/10.1080/08941920903360372

Hastings, C., and J. Williams, editors. 2014. Idaho's 2014 integrated report. Idaho Department of Environmental Quality (IDEQ), Water Quality Division. http://www.deq.idaho.gov/ media/60179654/idaho-2014-integrated-report.pdf
Hicks, C. C., T. R., McClanahan, J. E., Cinner, and J. M. Hills. 2009. Trade-offs in values assigned to ecological goods and services associated with different coral reef management strategies. Ecology and Society 14(1): 10. http://dx.doi. org/10.5751/ES-02712-140110

Hoff, H. 2009. Global water resources and their management. Current opinion in Environmental Sustainability 1:141-147. http:// dx.doi.org/10.1016/j.cosust.2009.10.001

Hopkins, J. M., A. M. Marcarelli, and H. A. Bechtold. 2011. Ecosystem structure and function are complementary measures of water quality in a polluted, spring-influenced river. Water, Air, and Soil Pollution 214(1-4):409-421. http://dx.doi.org/10.1007/ s11270-010-0432-y

Inglehart, R. 1995. Public support for environmental protection: objective problems and subjective values in 43 societies. Political Science and Politics 28:57-72. http://dx.doi.org/10.1017/ $\underline{\mathrm{S} 1049096500056080}$

Ives, C. D., M. Giusti, J. Fischer, D. J. Abson, K. Klaniecki, C. Dorninger, J. Laudan, S. Barthel, P. Abernethy, B. Martín-López, and C. M. Raymond. 2017. Human-nature connection: a multidisciplinary review. Current Opinion in Environmental Sustainability 26:106-113. http://dx.doi.org/10.1016/j.cosust.2017.05.005

Khakzad, S., and D. Griffith 2016. The role of fishing material culture in communities' sense of place as an added-value in management of coastal areas. Journal of Marine and Island Cultures 5(2):95-117. http://dx.doi.org/10.1016/j.imic.2016.09.002

Larson, K. L., R. Stotts, A. Wutich, A. Brewis, and D. White. 2016. Cross-cultural perceptions of water risks and solutions across select sites. Society and Natural Resources 29(9):1049-1064. http://dx.doi.org/10.1080/08941920.2015.1122132

Laurans, Y., A. Rankovic, R. Bille, R. Pirard, and L. Mermet. 2013. Use of ecosystem services economic valuation for decision making: questioning a literature blindspot. Journal of Environmental Management 119:208-219. http://dx.doi.org/10.1016/ j.jenvman.2013.01.008

Leduc, C., A. Pulido-Bosch, and B. Remini. 2017. Anthropization of groundwater resources in the Mediterranean region: processes and challenges. Hydrogeology Journal 25(6):1529-1547. http://dx. doi.org/10.1007/s10040-017-1572-6

Legendre, P., and L. Legendre, editors. 1998. Numerical ecology. Second English edition. Developments in environmental modelling. Volume 20. Elsevier, New York, New York, USA.

Leslie, H. M., X. Basurto, M. Nenadovic, L. Sievanen, K. C. Cavanaugh, J. J. Cota-Nieto, B. E. Erisman, E. Finkbeiner, G. Hinojosa-Arango, M. Moreno-Báez, S. Nagavarapu, S. Reddy, A. Sánchez-Rodríguez, K. Siegel, J. J. Ulibarria-Valenzuela, A. Hudson Weaver, and O. Aburto-Oropeza. 2015. Operationalizing the social-ecological systems framework to assess sustainability. Proceedings of the National Academy of Sciences 112(19)59795984. http://dx.doi.org/10.1073/pnas. 1414640112

López-Rodríguez, M., A. J. Castro, J. Cabello, S. Jorreto, and H. Castro. 2015. Science-policy interface approach for dealing with water environmental problems. Environmental Science and Policy 50:1-14. http://dx.doi.org/10.1016/j.envsci.2015.01.013 
López-Santiago, C. A., E. Oteros-Rozas, B. Martín-López, T. Plieninger, E. González Martín, and J. A. González. 2014. Using visual stimuli to explore the social perceptions of ecosystem services in cultural landscapes: the case of transhumance in Mediterranean Spain. Ecology and Society 19(2): 27. http://dx. doi.org/10.5751/ES-06401-190227

Maass, M., P. Balvanera, P. Bourgeron, M. Equihua, J. Baudry, J. Dick, M. Forsius, L. Halada, K. Krauze, M. Nakaoka, D. E. Orenstein, T. W. Parr, C. L. Redman, R. Rozzi, M. Santos-Reis, A. M. Swemmer, and A. Vădineanu. 2016. Changes in biodiversity and trade-offs among ecosystem services, stakeholders, and components of well-being: the contribution of the International Long Term Ecological Research network (ILTER) to Programme on Ecosystem Change and Society (PECS). Ecology and Society 21(3): 31. http://dx.doi.org/10.5751/ES-08587-210331

Marcarelli, A. M., R. W. V. Kirk, and C. V. Baxter. 2010. Predicting effects of hydrologic alteration and climate change on ecosystem metabolism in a western US river. Ecological Applications 20(8):2081-2088. http://dx.doi.org/https://doi. org/10.1890/09-2364.1

Martín-López, B., E. Gómez-Baggethun, M. García-Llorente, and C. Montes. 2014. Trade-offs across value-domains in ecosystem services assessment. Ecological Indicators 37:220-228. http://dx.doi.org/10.1016/j.ecolind.2013.03.003

Martín-López, B., I. Iniesta-Arandia, M. García-Llorente, I. Palomo, I. Casado-Arzuaga, D. García Del Amo, E. GómezBaggethun, E. Oteros-Rozas, I. Palacios-Agundez, B. Willaarts, J. A. González, F. Santos-Martín, M. Onaindia, C. LópezSantiago, and C. Montes. 2012. Uncovering ecosystem services bundles through social preferences. PLoS One 11: e38970. http:// dx.doi.org/10.1371/journal.pone.0038970

Millennium Ecosystem Assessment (MA). 2005. Millennium Ecosystem Assessment synthesis report. Island Press, Washington, D.C., USA.

Norström, A. V., P. Balvanera, M. Spierenburg, and M. Bouamrane. 2017. Programme on Ecosystem Change and Society: knowledge for sustainable stewardship of socialecological systems. Ecology and Society 22(1): 47. http://dx.doi. org/10.5751/ES-09010-220147

Ostrom, E. 2009. General framework for analyzing sustainability of social-ecological systems. Science 325:419-422. http://dx.doi. org/10.1126/science. 1172133

Oteros-Rozas, E., F. Ravera, I. Palomo, T. Daw, E. L. Bohensky, J. Butler, R. Hill, J. Martin-Ortega, A. Quinlan, F. Ravera, I. RuizMallén, M. Thyresson, J. Mistry, I. Palomo, G. D. Peterson, T. Plieninger, K. A. Waylen, D. Beach, I. C. Bohnet, M. Hamann, J. Hanspach, K. Hubacek, S. Lavorel, and S. Vilardy. 2015. Participatory scenario planning in place-based social-ecological research: insights and experiences from 23 case studies. Ecology and Society 20(4): 32. http://dx.doi.org/https://doi.org/10.5751/ ES-07985-200432

Petrich. 2016. Treasure Valley domestic commercial municipal industrial (DCMI) water-demand projections. Report to the Idaho Water Resource Board and U.S. Army Corps of Engineers. [online] URL: https://www.idwr.idaho.gov/files/news-release/20160329news-release-2016-08.pdf
Pisano, I., and M. Lubell. 2015. Environmental behavior in crossnational perspective: a multilevel analysis of 30 countries. Environment and Behavior 49(1):31-58. http://dx.doi. org/10.1177/0013916515600494

Quintas-Soriano, C., A. J. Castro, H. Castro, and M. GarcíaLlorente. 2016. Impacts of land use change on ecosystem services and implications for human well-being in Spanish drylands. Land Use Policy 54:534-406 http://dx.doi.org/10.1016/j.landusepol.2016.03.011

Quintas-Soriano, C., A.J. Castro, M. García-Llorente, J. Cabello, and H. Castro. 2014. From supply to social demand: a landscapescale analysis of the water regulation service. Landscape Ecology 400:1069-1082 http://dx.doi.org/10.1007/s10980-014-0032-0

Quintas-Soriano, C., M. García-Llorente, and A. J. Castro. 2018. What ecosystem service science has achieved in Spanish drylands? Evidences of need for transdisciplinary science. Journal of Arid Environments: in press. http://dx.doi.org/10.1016/j.jaridenv.2018.01.004

R Core Team. 2015. R: a language and environment for statistical computing [Programa informàtico]. R Foundation for Statistical Computing, Vienna, Austria.

Rao, C. R. 1964. The use and interpretation of principal component analysis in applied research. Sankhyâ: The Indian Journal of Statistics, Series A 26(4):329-358.

Rodríguez, J. P., T. D. Beard, Jr., E. M. Bennett, G. S. Cumming, S. Cork, J. Agard, A. P. Dobson, and G. D. Peterson. 2006. Tradeoffs across space, time, and ecosystem services. Ecology and Society 11(1): 28. http://dx.doi.org/10.5751/ES-01667-110128

Running, K. 2013. World citizenship and concern for global warming: building the case for a strong international civil society. Social Forces 92(1):377-399. http://dx.doi.org/10.1093/sf/sot077

Sabo, J. L., T. Sinha, L. C. Bowling, G. H. W. Schoups, W. W. Wallender, M. E. Campana, K. A. Cherkauer, P. L. Fuller, W. L. Graf, J. W. Hopmans, J. S. Kominoski, C. Taylor, S. W. Trimble, R. H. Webb, and E. E. Wohl. 2010. Reclaiming freshwater sustainability in the Cadillac Desert. Proceedings of the National Academy of Sciences of the United States of America 107:2126321270. http://dx.doi.org/10.1073/pnas. 1009734108

Tallis, H., and S. Polasky. 2009. Mapping and valuing ecosystem services as an approach for conservation and natural-resource management. Annals of the New York Academy of Sciences 1162:265-283. http://dx.doi.org/10.1111/j.1749-6632.2009.04152. $\underline{x}$

Turkelboom F., S. Jacobs, E. Kelemen, M. García-Llorente, F. Baró, P. Berry, M. Leone, M. Thoonen, M. Termansen, Á. Kalóczkai, A. Vadineanu, A. J. Castro, B. Czúcz, C. Röckmannx, D. Wurbs, D. N. Barton, D. Odee, E. Preda, E. Gómez-Baggethun, E. Stange, G. Rusch, G. Martínez Pastur, I. Palomo, J. Dick, J. Casaer, J. van Dijk, J. A. Priess, J. Langemeyer, J. Mustajoki, L. Kopperoinen, M. J. Baptist, P. L. Peri, R. Mukherjee, R. Aszalós, S. B. Roy, S. Luque, and V. Rusch. 2018. When we cannot have it all: ecosystem services trade-offs in real-life planning contexts. Ecosystem Services 29:566-578. http://dx.doi.org/10.1016/j. ecoser.2017.10.011

Turner, R. K., S. Morse-Jones, and B. Fisher. 2010. Ecosystem valuation, a sequential decision support system and quality assessment issues. Annals of the New York Academy of Sciences 
1185:79-101. http://dx.doi.org/10.1111/j.1749-6632.2009.05280. $\underline{\mathrm{X}}$

Vaughn, C. C. 2017. Ecosystem services provided by freshwater mussels. Hydrobiologia 810(10):15-27. http://dx.doi.org/10.1007/ s10750-017-3139-X

Xu, W., S. E. Lowe, and R. M. Adams. 2014. Climate change, water rights, and water supply: the case of irrigated agriculture in Idaho. Water Resources Research 50:9675-9695. http://dx.doi. org/10.1002/2013WR014696 
APPENDIX 1. Survey design.

DATE No SURVEY

INTERVIEWER NAME

Idaho State University and Boise State University are cooperatively working on a study examining the links between humans and nature. We are studying the benefits provided by the Portneuf Watershed and their relationship with different land use and climate scenarios. To do this we are surveying locals and tourists in the area. It would be helpful to know your opinion/perception through this survey. Would you like to answer? Thank you! Remember that all responses are anonymous and it only takes 15 min. There are no "right answers", just tell us what you think.

\section{Section A: Ecosystem Benefits Perception in the Watershed}

Nature is providing, directly or indirectly, benefits to human, which are essential for our wellbeing. For instance, humans get food from oceans, coastal protection from storms or pleasure by visiting beaches.

1. Do you think the Watershed provides benefits that contribute to human wellbeing of the region? How many benefits? (Here it's important to explain what we mean by the Watershed) 1. Very many2. Many3. Few4. Very little to non Can you give me examples of some potentials benefits? (All they consider)

\section{Section B: Variables related to environmental behavior}

1. Where do you live? (zip code)

2. What brings you to the Watershed?

! WATERSHED RESIDENT (if they live in any of the Watershed counties)

! TOURIST (citizen visiting the Watershed)

! BUSINESS (nonresident in the Portneuf Watershed but working in the area)

3. Have you visited the Portneuf River?

! Yes ! No - Are you planning to visit?

4. Do your parents/grandparents come from this area?

! No ! Yes - How many generations has your family lived in the Portneuf Watershed?

5. What are your top 3 outdoor recreation activities?.

1. Mountain biking2.

Bait Fishing3. Boating4. Hiking/running5. Off-roading (ATV, snowmobile)6. Fly fishing7. Hunting8. Camping/backpacking9. Climbing10. Skiing (cross-country-downhill)11. Other, which one? groups? 1. Yes, what type? (! Environmental; ! Social; ! Leisure; ! Work; ! Other) Specifically? 6. Do you belong to any community No 7. Are you active in community affairs?

! Yes (for example, attend city meetings, neighborhood association, or church group).

! No

7a- IF YES: Do you think your opinion is considered in decision making?

! Yes; How?.

! No, why?.

8. Do you think that government decisions are affecting the health of the Portneuf Watershed? 
! No ! Yes - In what sense/way?.

9. What geographic location do you identify with most? (Chose just 1): 1. USA2. Western USA3. Idaho4. SE Idaho5. City/county of residence6. Other: 10 . What year were you born?

11. What is the highest level of school you have completed/the highest degree you have received?

! Less than high school degree

! High school degree or equivalent (e.g. GED)

! Some college but no degree

! Associate degree

! Bachelor degree

! Graduate degree

! Other

! Prefer not to say

12. What is your profession? (If retired, what did you do?)

13. What is your annual household income? 1. $<\$ 19,9992$. $\$ 20,000$ - $\$ 39,9993 . \$ 40,000$ - $\$ 59,9994 . \$ 60,000$ - $\$ 79,9995$. $\$ 80,000$ $\$ 99,9996$. > $\$ 100,0007$. Prefer not to say 14 . How would you describe your ethnic background?

! White, Caucasian (Non-Hispanic) ! Native Hawaiian or other Pacific

! Black, African-American Islander..

! Native American ! Latino or Hispanic

Tribe or Tribe Affiliation ! Other:

! Asian American! Prefer not to say

15. Gender: 1. Female2. Male 
APPENDIX 2. Summary of the variables obtained from the questionnaire and used for the analyses performed in the study. RDA = Redundancy Analysis; KW = Kruskal-Wallis Test; M-W = Mann-Whitney U-test.

\begin{tabular}{|c|c|c|c|c|}
\hline \multirow{2}{*}{\multicolumn{5}{|c|}{$\begin{array}{l}\text { Code of variable } \\
\text { Dependent variables }\end{array}$}} \\
\hline \multirow{2}{*}{\multicolumn{5}{|c|}{ Category of ecosystem services identified }} \\
\hline & & & & \\
\hline Prov. & $\begin{array}{l}\text { Category of ecosystem service perceived as } \\
\text { important by respondent }\end{array}$ & Nominal & Provisioning & $\mathrm{K}-\mathrm{W}$ \\
\hline Reg. & & & Regulating & \\
\hline Cult. & & & Cultural & \\
\hline \multicolumn{5}{|c|}{ Ecosystem services listed in the free-listing } \\
\hline Agric & Food from agriculture & Dummy & $1=$ yes, $0=$ no & RDA \\
\hline Water & Freshwater & Dummy & $1=$ yes, $0=$ no & RDA \\
\hline Energy & Clean energy & Dummy & $1=$ yes, $0=$ no & RDA \\
\hline Climate & Climate regulation & Dummy & $1=$ yes, $0=$ no & RDA \\
\hline Habitat & Habitat for species & Dummy & $1=$ yes, $0=$ no & RDA \\
\hline Air $q$ & Air quality & Dummy & $1=$ yes, $0=$ no & RDA \\
\hline Water $q$ & Water quality & Dummy & $1=$ yes, $0=$ no & RDA \\
\hline Tourism & Tourism & Dummy & $1=$ yes, $0=$ no & RDA \\
\hline Esthetics & Esthetic values & Dummy & $1=$ yes, $0=$ no & RDA \\
\hline Rec. hunting & Recreational hunting & Dummy & $1=$ yes, $0=$ no & RDA \\
\hline Rec. fishing & Recreational fishing & Dummy & $1=$ yes, $0=$ no & RDA \\
\hline Existence & Existence values & Dummy & $1=$ yes, $0=$ no & RDA \\
\hline \multicolumn{5}{|c|}{ Independent variables } \\
\hline \multicolumn{5}{|c|}{ Environmental behavior } \\
\hline Association & & Dummy & $1=$ yes, $0=$ no & RDA; M-W \\
\hline \multicolumn{5}{|c|}{ Sociodemographic characteristics } \\
\hline Stakeholder & Stakeholder groups & Nominal & Resident (general public) & RDA; M-W \\
\hline & & & $\begin{array}{l}\text { Expert (employees from } \\
\text { state/federal agencies and } \\
\text { university) }\end{array}$ & \\
\hline Education & Respondents' formal studies level & Continuous & Ln (level education) & RDA \\
\hline \multirow[t]{3}{*}{ Age } & Age of respondents & Continuous & Ln (age) & RDA \\
\hline & Younger people $($ age $<30)$ & Dummy & $1=$ yes, $0=$ no & $\mathrm{M}-\mathrm{W}$ \\
\hline & Older people $($ age $>70)$ & Dummy & $1=$ yes, $0=$ no & $\mathrm{M}-\mathrm{W}$ \\
\hline Gender & & Nominal & $\begin{array}{l}\text { Female } \\
\text { Male }\end{array}$ & RDA; M-W \\
\hline \multirow[t]{2}{*}{ Income } & Annual income of respondents & Continuous & Ln (monthly income) & RDA \\
\hline & & Nominal & $\begin{array}{l}\text { Less than High School } \\
\text { High School } \\
\text { University }\end{array}$ & $\mathrm{K}-\mathrm{W}$ \\
\hline \multirow{4}{*}{$\begin{array}{l}\text { Place-based } \\
\text { research sites }\end{array}$} & Study sites & Nominal & Treasure Valley & RDA; K-W \\
\hline & & & Portneuf Valley & \\
\hline & & & Kiamichi River & \\
\hline & & & Spanish Watersheds & \\
\hline \multicolumn{5}{|c|}{ Ecological characteristics } \\
\hline Dev & Percentage of developed lands & Continuous & Percentage & RDA \\
\hline For & Percentage of forest land use & Continuous & Percentage & RDA \\
\hline Agri & Percentage of agricultural land use & Continuous & Percentage & RDA \\
\hline Wat & Percentage of water land use & Continuous & Percentage & RDA \\
\hline Warmest month & $\begin{array}{l}\text { Average temperature of the warmest } \\
\text { month }\end{array}$ & Continuous & Average temperature & RDA \\
\hline Wettest month & Average precipitation of the wettest month & Continuous & Average precipitation & RDA \\
\hline
\end{tabular}


APPENDIX 3. Percentage of respondents that provide examples of ecosystem services and differences of the importance perceived among place-based research sites as calculated by the Kruskal-Wallis test and Dunn groups.

\begin{tabular}{|c|c|c|c|c|c|c|c|c|c|}
\hline Ecosystem services & $\begin{array}{l}\text { Treasure } \\
\text { Valley }\end{array}$ & & $\begin{array}{l}\text { Portneuf } \\
\text { Valley }\end{array}$ & & $\begin{array}{l}\text { Kiamichi } \\
\text { river }\end{array}$ & & $\begin{array}{l}\text { Spanish } \\
\text { watersheds }\end{array}$ & & $\begin{array}{l}\text { Kruskal-Wallis } \\
\text { test }\end{array}$ \\
\hline \multicolumn{10}{|l|}{ Provisioning } \\
\hline Agriculture & 25 & $\mathrm{~B}$ & 25 & $\mathrm{~B}$ & 12 & A & 27 & B & $<0.0001$ \\
\hline Water & 13 & B & 40 & $\mathrm{D}$ & 31 & $\mathrm{C}$ & 4 & A & $<0.0001$ \\
\hline Energy & 4 & $\mathrm{~B}$ & 2 & $\mathrm{AB}$ & 0.3 & A & 3 & $\mathrm{AB}$ & 0.011 \\
\hline \multicolumn{10}{|l|}{ Regulating } \\
\hline Climate & 3 & A & 0.3 & A & 0 & A & 15 & B & $<0.0001$ \\
\hline Habitat & 5 & $\mathrm{~B}$ & 6 & $\mathrm{~B}$ & 3 & $\mathrm{AB}$ & 0.6 & A & $<0.0001$ \\
\hline Air quality & 12 & $\mathrm{~B}$ & 3 & A & 0 & A & 9 & $\mathrm{~B}$ & $<0.0001$ \\
\hline Water quality & 6 & B & 4 & $\mathrm{~B}$ & 1 & A & 0 & A & $<0.0001$ \\
\hline \multicolumn{10}{|l|}{ Cultural } \\
\hline Tourism & 50 & $\mathrm{~B}$ & 44 & B & 45 & $\mathrm{~B}$ & 23 & A & $<0.0001$ \\
\hline Esthetics & 32 & $\mathrm{C}$ & 6 & $\mathrm{AB}$ & 0.3 & A & 12 & $\mathrm{~B}$ & $<0.0001$ \\
\hline Rec. hunting & 9 & $\mathrm{~B}$ & 3 & A & 4 & A & 1 & A & $<0.0001$ \\
\hline Rec. fishing & 15 & $\mathrm{~B}$ & 16 & $\mathrm{~B}$ & 25 & $\mathrm{C}$ & 0.2 & A & $<0.0001$ \\
\hline Existence & 8 & A & 15 & B & 3 & A & 4 & A & $<0.0001$ \\
\hline$N$ & 402 & & 326 & & 308 & & 475 & & \\
\hline
\end{tabular}


APPENDIX 4. Factor loadings derived from the redundancy analysis (RDA), the eigenvalues and the variance explained of the first four factors.

Eigenvalue

Percentage variance explained

Cumulative \% variance explained

Total inertia

Standardized canonical coefficients

LN (monthly income)

LN (age)

LN (education)

Warmest Month

Wettest Month

LU agri

LU for

LU urb

LU wat

Stakeholders-Expert

Stakeholders-Resident

Environmental behavior-No

Environmental behavior-Yes

Sense of place-City/County

Sense of place-Country

Sense of place-Province/Region

Sense of place-World/global

Gender-Female

Gender-Male

Case study-Kiamichi river

Case study-Portneuf valley

Case study-Spanish watersheds

Case study-Treasure valley

$\begin{array}{llll}\text { Axes 1 } & \text { Axes 2 } & \text { Axes 3 } & \text { Axes 4 } \\ 0.045 & 0.027 & 0.01 & 0.003 \\ 49.021 & 29.438 & 10.441 & 3.744 \\ 49.021 & 78.459 & 88.9 & 92.644 \\ 4.041 & 2.427 & 0.861 & 0.309 \\ & & & \\ 0.047 & 0.041 & 0.013 & -0.090 \\ 0.041 & \mathbf{0 . 0 5 7} & -0.090 & 0.046 \\ -0.048 & \mathbf{0 . 1 2 5} & -0.012 & 0.106 \\ 0.008 & \mathbf{- 0 . 0 9 9} & 0.008 & 0.186 \\ 0.034 & \mathbf{- 0 . 1 6 9} & 0.351 & -0.187 \\ \mathbf{- 0 . 1 5 5} & \mathbf{- 0 . 2 3 3} & 0.113 & -0.075 \\ -0.010 & -\mathbf{0 . 0 5 9} & 0.025 & 0.037 \\ \mathbf{- 0 . 1 1 5} & -\mathbf{0 . 2 0 0} & 0.114 & 0.096 \\ 0.008 & 0.041 & 0.010 & -0.051 \\ 0.012 & 0.044 & 0.054 & 0.017 \\ -0.012 & -0.044 & -0.054 & -0.017 \\ -0.006 & -0.022 & -0.027 & -0.007 \\ 0.006 & 0.022 & 0.027 & 0.007 \\ -0.037 & -0.004 & 0.018 & 0.001 \\ 0.040 & 0.023 & 0.041 & 0.013 \\ -0.007 & -0.021 & -0.051 & -0.008 \\ 0.010 & 0.021 & 0.000 & -0.022 \\ -0.011 & 0.003 & 0.006 & 0.012 \\ 0.011 & -0.003 & -0.006 & -0.012 \\ \mathbf{0 . 1 6 3} & -0.077 & -0.396 & -0.002 \\ \mathbf{0 . 1 9 4} & -0.212 & 0.255 & 0.080 \\ \mathbf{- 0 . 2 9 8} & 0.008 & 0.042 & 0.065 \\ -0.016 & \mathbf{0 . 2 5 9} & 0.080 & -0.140\end{array}$

